\title{
Access or Barrier? Tuition and Fee Legislation for Undocumented Students across the States
}

\author{
David H. K. Nguyen \& Gabriel R. Serna
}

\begin{abstract}
States have responded in a variety of ways to undocumented immigration and its implications for higher education. Some states have allowed undocumented students to seek an affordable college education while others have created barriers. This article highlights the piecemeal legislation that the states have passed in order to respond to the needs of undocumented students; namely, policies allowing undocumented students in-state resident tuition. It also considers the policy impacts on undocumented students and the institutions and faculty that serve them.
\end{abstract}

\section{Keywords}

Undocumented immigration, Higher education, In-state tuition

This is the author's manuscript of the article published in final edited form as:

Nguyen, D. H. K., \& Serna, G. R. (2014). Access or Barrier? Tuition and Fee Legislation for Undocumented Students across the States. The Clearing House: A Journal of Educational Strategies, Issues and Ideas, 87(3), 124-129. 


\section{Introduction}

It has been almost 30 years since Congress addressed comprehensive immigration reform. This lack of attention means that every year over 65,000 undocumented students graduate high school only to discover that their futures are uncertain because of laws and policies that create additional barriers to their attainment of higher education and successful entry into the workforce (Passel and Cohn 2009). Proponents of comprehensive immigration reform have proposed and supported the passing of the Development, Relief, and Education for Alien Minors (DREAM) Act in order to include undocumented immigrants within mainstream society and allow them to contribute to the nation's workforce, economy, and overall cultural fabric.

However, the political divide in Congress has repeatedly stalled immigration reform efforts and has left many undocumented students wondering when they will be able to fully participate legally in a society of which they are already very much a part. As a result, many states have taken it upon themselves to provide temporary relief by allowing undocumented students to pay in-state resident tuition rates when pursuing higher education. Although this does not resolve all of the financial issues faced by these students, it does help to lower the cost barriers they confront as they seek advanced education.

This article examines the current landscape of laws and policies impacting undocumented students and their attainment of an affordable higher education. Through Plyler v. Doe, the U.S. Supreme Court has guaranteed primary and secondary education to all children regardless of citizenship. After high school graduation, however, no such guarantee exists; therefore, many states have made it a priority to further their investments in these youths beyond $\mathrm{K}-12$ and to help make college more accessible. Other states, instead, have opted to purposefully make higher education unaffordable or inaccessible by treating undocumented students as nonresidents based on their immigration status. These laws and policies have a variety of implications for these young students, as well as the schools, faculty, counselors, and higher education institutions that serve them. These implications are carefully examined in this article.

\section{Setting the Context: Plyler v. Doe and the K-12 Guarantee}

In 1982 the U.S. Supreme Court in Plyer v. Doe guaranteed undocumented children a free public K-12 education. In Plyer, the Court prohibited states from denying students free access to education and school districts from charging tuition based on their citizenship status. Plyler, along with Brown v. Board of Education, Regents of the University of California v. Bakke, and the Gratz v. Bollinger and Grutter v. Bollinger decisions, are landmark cases affording equal opportunity in education (Lopez 2005). These were the first instances in which the U.S. Supreme Court stated that undocumented immigrants are protected under the Equal Protection Clause of the Fourteenth Amendment of the U.S. Constitution (Lopez 2005; Olivas 2004).

In Plyler, a Texas statute withheld state funding to educate children who had not been legally admitted into the United States and allowed school districts to deny enrollment to such students. The Court ruled that this denial of education would create a "lifetime of hardship" and a "permanent underclass" of individuals, and that "it is doubtful that any child may reasonably be expected to succeed in life if he is denied the opportunity to an education" (Lopez 2005, 1389, citing Plyler). Moreover, it is important to note that in response to the argument that undocumented families drain public resources and do not contribute to social services, the Court stated that there was no "evidence. . . suggesting that illegal entrants impose any significant burden on the State's economy" (Plyler 1982, 228). Additionally, the 
opinion stated that the Court of Appeals found that undocumented families contribute equally to the funding of education as do citizens or legal residents (Plyler, 588-89). Since Texas was not able to show a substantial state interest to deny "a discrete group of innocent children" education that it otherwise offers to others residing within its borders, the U.S. Supreme Court invalidated the law, giving the right to K-12 education (Plyler 1982, 229-30).

Unfortunately, the opportunity to an education does not extend to higher and postsecondary education. Although Plyler guarantees primary and secondary education to undocumented students, a high school diploma is no longer sufficient to compete in today's labor market (Gonzales 2009). Undocumented students face a variety of obstacles, some erected by the states, to accessing higher education, including the denial of admission, a lack of financial aid, and the inability to pay an in-state resident tuition just to name a few. In the section that follows we highlight efforts at the federal level to promote access to higher education for undocumented students.

\section{Federal Attempts at Comprehensive Immigration Reform}

Congress has not passed comprehensive immigration reform since the Immigration Reform and Control Act of 1986 (IRCA). The IRCA created two new immigration policies. First, it required employers to attest to their employees' immigration status and made it illegal to knowingly hire undocumented immigrants. Second, it "legalized" certain seasonal agricultural migrant workers and about three million other undocumented immigrants who entered and resided in the U.S. continuously since January 1, 1982, which became known as "amnesty" (Baker 1997). Ten years later, Congress passed the Personal Responsibility and Work Opportunity Reconciliation Act (PRWORA) and the Illegal Immigration Reform and Immigrant Responsibility Act (IIRIRA). These two acts dramatically changed the outlook for undocumented immigrants and affected federal social welfare and health benefits for them, which notwithstanding state residence also denied education benefits to undocumented students if not afforded to a U.S. national (Olivas 2004; Lopez 2005). If a state desired to afford undocumented immigrants with in-state resident tuition, it must do so through passing legislation; Texas followed suit in 2001 and, as can be seen in Tables 1 and 2, many states took action soon after.

Also in 2001, the first version of the DREAM Act was introduced with hopes that it would solve this predicament for all undocumented students nationally. Under certain circumstances, the DREAM Act would allow adjustment to legal status for those who graduate from a U.S. high school, arrived to the United States as minors, and lived in the country continuously for at least five years prior to the bill's passage. Two years of military service or higher education would allow temporary residency for six years, and within those six years, permanent residency would be obtained if the undocumented student acquired a higher education degree, completed two years of higher education, or served two years in the armed forces. The bill would repeal Section 505 of the IIRIRA, which allows states to determine residency of undocumented students for the purpose of in-state resident tuition (Olivas 2009).

Since 2001 several forms of the DREAM Act have been introduced. The most recent version, drawn up in 2010, among other things, did not repeal Section 505 of IIRIRA and forced states to continue charging nonresident tuition if states had not acted otherwise. It lowered the age cap for eligibility from 35 to 29 years of age and further limited eligibility based on additional criteria involving marriage fraud, alleged crimes, and so on. Although the revised DREAM Act included more restrictions, it still failed to 
pass the Senate in 2010 and again in 2011. Most recently, supporters withheld their votes, demanding increased immigration enforcement.

Because of these failed attempts, states responded by passing their own versions of the DREAM Act. In July 2011 California enacted the California DREAM Act, giving undocumented students access to private college scholarships for state schools. In addition, in 2012 President Barack Obama announced his administration's Deferred Action for Childhood Arrivals (DACA) program. This program gives temporary reprieve to undocumented immigrants, enabling them to enjoy certain benefits without a pathway to legal status. Some undocumented students have been able to take advantage of this program and fully engage in their communities without fear of disclosing their status; however, the struggle persists without concrete assurance of legal status.

Most recently, in 2013 a bipartisan group of eight senators proposed what later became known as the Border Security, Economic Opportunity, and Immigration Modernization Act of 2013. This act would create a pathway to citizenship for undocumented immigrants after legal immigrants receive their permanent residence status; a reduction in backlogs of those with advanced degrees in the science, technology, engineering, or math (STEM) fields; and improvement of work visa options for low-skill migrant workers. The bill passed in the Senate but not in the House of Representatives, and as a result, comprehensive immigration reform at the federal level remains at a standstill as other issues are of more central concern for Congress.

\section{State Action on In-state Resident Tuition for Undocumented Students}

As just mentioned, federal-level comprehensive immigration reform has stalled. This has resulted in state governments becoming the primary arbiters of this type of legislation. Moreover, failed federal attempts at comprehensive immigration reform means that across the country undocumented students must rely on piecemeal state legislation in order to access pathways to higher education and in some instances face state-erected barriers to college. According to the National Conference of State Legislatures (NCSL; 2013), at least 16 states have enacted legislation that promotes access to higher education for undocumented students through allowing in-state tuition benefits. Table 1 outlines the history and some highlights of this legislative, and in some instances legal, process.

Conversely, a number of states have legislated barriers to college access for undocumented students by disallowing them to qualify for in-state tuition, among other things. According to the NCSL, the states listed in Table 2 have adopted legislation banning in-state tuition for undocumented students as of July 2013. Table 2 also notes that some states have instead disallowed enrollment of undocumented students altogether.

States are not the only ones participating in establishing policies that impact undocumented students. In at least three states, boards of regents have taken action as well. Table 3 outlines the policy action undertaken by boards in Georgia, Michigan, and Rhode Island.

Clearly, many states have been busy dealing with the question of in-state resident tuition for undocumented students. While a number of states have helped clear some obstacles for undocumented students to access a college education, even these legislative efforts may not be enough. This is because evidence shows that few undocumented students have taken advantage of in-state tuition laws (Emma 2013). 
For example, at the University of Connecticut, with total enrollments exceeding 18,000 , only 33 undocumented students have benefitted from the law. At the University of California, Berkeley, which has over 25,000 undergraduates, only 250 undocumented students have used the law to their advantage (Emma 2013). These numbers may indicate that, although these students now qualify for instate tuition, the price of college remains too high for them to access higher education. Some states, such as Colorado and California, have attempted to remedy this situation by allowing undocumented students access to state financial aid. However, without access to federal monies, it is unlikely that cost barriers can be diminished for this group of students. This is because federal financial aid is often the only mechanism that provides sufficient funds to allow one to attend even the least-costly institutions of higher education. Moreover, the impacts of being unable to access college means that both educational and job opportunities for undocumented students remain significantly limited.

\section{Pipeline and Societal Implications}

State legislation of this sort impacts not just undocumented students but also the schools they attend, those who teach and counsel them, and the institutions of higher education that serve them. The implications of these legislative and judicial actions will likely stretch across the P-20 system in both states that allow in-state tuition benefits and those that do not. On college campuses where undocumented students can avail themselves of in-state tuition benefits, for example, faculty and staff will have to examine the ways in which they support these students. Support services that take into account the special circumstances faced by undocumented students will become necessary. For example, Baum and Flores (2011) suggest that few of these students have the necessary social capital and overall support that can help them succeed in college. Moreover, although these efforts may be unfunded or require reallocation of limited resources, they may help institutions more closely align their actions with their stated public service and social justice missions. This is especially the case at statesupported schools where this legislation or decisions by boards of trustees have made in-state tuition benefits possible for undocumented students.

For schools and school districts, teachers will encounter new occasions for encouraging undocumented students to continue on to college. As mentioned earlier, Plyler gives the right to a $\mathrm{K}-12$ education, and as a result many undocumented youth are unaware of their status until they apply for a part-time job or college admission. This further contributes to stress and fear for undocumented students. The restrictions that come from immigration policy create an immense fear of deportation and ultimately a life filled with anxiety for those who are undocumented (Abrego 2008). Teachers are more often than not the undocumented student's first point of contact and advocate given that students have been able to build a relationship of trust with teachers throughout the years. As a result, teachers are most apt to respond to the needs of these students and help them navigate the maze of policies and benefits to continue their education at a college or university. Moreover, students may fear that the disclosure of their status may bring legal issues to them and their families, even after the issuance of the DACA program.

As Baum and Flores $(2011,187)$ suggest: "Many also lack support networks that would bolster aspirations and expectations about postsecondary education." This is where public schools can help fill the information gap. They can also help students prepare for college-level work, in some cases master English, and help them make successful transitions between high school and college. In a similar vein, guidance counselors will have opportunities to advise students to attend college from a much earlier 
age, since price barriers have been lowered, although still not eliminated. Administrators will also play an important role. In their decision-making capacities they will be required to allocate resources to helping more of these students successfully navigate the P-20 pipeline.

While we have highlighted some of the implications of state action allowing in-state tuition benefits, it is also necessary to highlight some concerns that might arise for educators and administrators in states disallowing these benefits for undocumented students. That a student who might otherwise be prepared to attend college cannot do so because of price considerations is itself a dilemma. For undocumented students, state legislation that further erects barriers to college access accentuates this dilemma. We do not argue that in-state benefits for undocumented students will create unfettered access to college. Rather, we suggest, much like Baum and Flores (2011), that state legislation prohibiting the extension of tuition benefits to students further decreases the likelihood that they will attend college.

For the country as a whole, the plight of these students should be of concern. Baum and Flores (2011) provide evidence that the number of undocumented children of immigrants younger than age 18 is rising. This measure is only surpassed by the number of U.S. citizens born to undocumented parents, many of whom have few resources to support continued education for their children. In other words, for many undocumented students, socioeconomic status is an issue. Undocumented students and their families often reside in poorer areas, with under-resourced schools and limited job opportunities. This means that they have fewer chances to access the needed resources and information required to steer them onto successful educational pathways (Baum and Flores 2011). Moreover, a primary barrier to accessing higher education remains state laws that make enrolling in college difficult, if not impossible, for many of these students. The direness of the situation is intensified when undocumented students face out-of-state tuition rates, which make it inordinately costly to access higher education. Limited access to financial aid, both state and federal, coupled with the socioeconomic concerns cited previously, leave many undocumented students without fruitful alternatives (Chin and Juhn 2010).

Finally, it is important to note that the losses that arise as a result of bans on in-state tuition benefits are not borne only by these students. Recent research has shown that undocumented students not only migrate to states that offer in-state tuition benefits, but that they are more likely to enroll and persist in larger numbers (Baum and Flores 2011; Flores 2010; Flores and Horn 2009; Flores and Kaushal 2008). In other words, states are losing a potentially large number of otherwise skilled, educated workers.

Because the education pipeline does not end once students graduate from high school or college, job outcomes and the social good are negatively impacted when a significant proportion of the population is limited by its undocumented status. In order for the communities and states in which undocumented students live and learn to thrive, there must be not only access to a good education but also a mechanism that allows them to access that education without significant price concerns. As long as the federal government is unable to pass comprehensive reform, states will remain the primary players in this legislative area and students will have to rely on piecemeal policies to attend and pay for college. For educators, the ability to effectively guide and prepare undocumented students at all levels for future life success will be highly dependent on the state in which their students reside. 


\section{Conclusion}

The myriad of federal and state policies impacting higher education for undocumented students can become cumbersome. Given that the federal attempts at passing comprehensive immigration legislation have stalled, some states have taken it upon themselves to ensure that their undocumented youth are afforded an opportunity to seek higher education; others have instead gone in the opposite direction. In this brief analysis we have outlined these actions and highlighted some pipeline and societal implications of such piecemeal legislation. We argue that without comprehensive reform at the federal level, the educational opportunities afforded to undocumented students will depend on the state in which they live. We also suggest that educational opportunities only set the foundation for future success in life and the betterment of society on the whole, and that state attempts at lowering cost barriers are a step in the right direction. 


\section{References}

1. Abrego, L. 2008. Legitimacy, social identity, and the mobilization of law: The effects of Assembly Bill 540 on undocumented students in California. Law and Social Inquiry 33(3): 709-34.

2. Baker, S.G. 1997. The "amnesty" aftermath: Current policy issues stemming from the legalization programs of the 1986 immigration reform and control act. International Migration Review 31(1), 5-27.

3. Baum, S., and S. Flores. 2011. Higher education and children in immigrant families. The Future of Children 21(1): 171-93.

4. Chin, A., and C. Juhn. 2010. Does reducing college costs improve educational outcomes for undocumented immigrants? Evidence from state laws permitting undocumented immigrants to pay in-state tuition at state college and universities. Cambridge, MA: National Bureau of Economic Research.

5. Emma, C. 2013. Immigration debate: Tuition breaks go largely unclaimed. Politico, July 7. http://www.politico.com/story/2013/07/an-in-state-tuition-deal-that-is-largely-unclaimed93795.html.

6. Flores, S. 2010. State "Dream Acts": The effects of in-state resident tuition policies on the college enrollment of undocumented Latino students in the United States. Review of Higher Education 33: 239-83.

7. Flores, S., and C. Horn. 2009. College persistence and undocumented students at a selective public university: A quantitative case study analysis. Journal of College Student Retention 11: 57-76.

8. Flores, S., and N. Kaushal. 2008. In-state tuition for the undocumented: Education effects on Mexican young adults. Journal of Policy Analysis and Management 27: 771-92.

9. Gonzales, R. 2009. Young lives on hold: The college dreams of undocumented students. New York: College Board Advocacy and Policy Center.

10. Jesse, D. 2013. U-M regents approve in-state tuition for undocumented students. The Detroit Free Press, July 18. http://www.freep.com/apps/pbcs.dll/article?AID=/201307181828/NEWS05/307180133 .

11. Lopez, M.P. 2005. Reflections on educating Latino and Latina undocumented children: Beyond Plyler v. Doe. Seton Hall Law Review 35(4), 10-44.

12. Morse, A., and K. Birnbach. 2012. In-state tuition and unauthorized immigrant students. In Issues and research, November 28. National Conference of State Legislatures. http://www.ncsl.org/issues-research/immig/in-state-tuition-and-unauthorized-immigrants.aspx.

13. National Conference of State Legislatures. 2013. Undocumented student tuition: State action. In Issues and research, July. http://www.ncsl.org/issues-research/educ/undocumented-studenttuition-state-action.aspx.

14. Olivas, M.A. 2004. IIRIRA, the Dream Act, and undocumented college student residency. Journal of College and University Law 30: 435.

15. Olivas, M.A. 2009. Political economy of the Dream Act and the legislative process: A case study of comprehensive immigration reform. The Wayne Law Review 55: 1757.

16. Passel, J., and D. Cohn. 2009. A portrait of unauthorized immigrants in the United States. Pew Hispanic Research Center, April 14. http://www.pewhispanic.org/files/reports/107.pdf.

17. Plyler v. Doe, 457 U.S. 202 (1982).

18. Plyler v. Doe, 628 F.2d. 448 (5th Cir. 1980). 
Tables

Table 1. Overview of State Actions Allowing In-State Tuition for Undocumented Students

\begin{tabular}{|c|c|c|}
\hline State & $\begin{array}{l}\text { Year } \\
\text { Adopted }\end{array}$ & Notes \\
\hline California & 2001 & $\begin{array}{l}\text { This legislation was challenged in Martinez v. Regents, } 241 \text { P.3d } 855 \\
\text { (2010), upheld by the California Supreme Court in } 2010 \text { and an appeal } \\
\text { declined for review by the U.S. Supreme Court in } 2011 .\end{array}$ \\
\hline Texas & 2001 & \\
\hline New York & 2002 & \\
\hline Utah & 2002 & \\
\hline Washington & 2004 & \\
\hline Oklahoma & 2004 & $\begin{array}{l}\text { Law amended giving authority for allowing in-state tuition to the } \\
\text { Oklahoma Board of Regents. Currently, authorized by regents. }\end{array}$ \\
\hline Illinois & 2004 & \\
\hline Kansas & 2004 & $\begin{array}{l}\text { This legislation was challenged in Day v. Sibelius, No. } 376 \text { F.Supp. } 2 d \\
1022 \text { (2005)/Day v. Bond, } 500 \text { F.3d } 1127 \text { (2007), upheld by U.S. Court of } \\
\text { Appeals for the 10th District and an appeal declined for review by the } \\
\text { U.S. Supreme Court in } 2008 \text {. }\end{array}$ \\
\hline New Mexico & 2005 & \\
\hline Nebraska & 2006 & \\
\hline Wisconsin & 2009 & Law was repealed in 2011. \\
\hline Maryland & 2011 & In-state tuition authorized at community colleges only. \\
\hline Connecticut & 2011 & \\
\hline Minnesota & 2013 & \\
\hline Oregon & 2013 & \\
\hline Colorado & 2013 & Initially banned in 2008, repealed in 2013. \\
\hline
\end{tabular}


Table 2. Overview of State Actions Banning In-State Tuition for Undocumented Students

\begin{tabular}{|l|l|l|}
\hline State & $\begin{array}{l}\text { Year } \\
\text { Adopted }\end{array}$ & Notes \\
\hline Arizona & 2006 & \\
\hline Georgia & 2008 & $\begin{array}{l}\text { This is not a ban on in-state tuition for undocumented students. Instead } \\
\text { students must prove that they are in the country legally to enroll at public } \\
\text { institutions of higher education. }\end{array}$ \\
\hline $\begin{array}{l}\text { South } \\
\text { Carolina }\end{array}$ & 2008 & \\
\hline Indiana & 2011 & $\begin{array}{l}\text { Same as South Carolina, however there are explicit rules disallowing } \\
\text { enrollment by undocumented students. }\end{array}$ \\
\hline Alabama & 2011 & $\begin{array}{l}\text { The state has a checkered history on this front changing its policy at least } \\
\text { five times since 2001. Currently, if a student can pay out-of state tuition } \\
\text { and has graduated from a North Carolina high school they can legally } \\
\text { enroll at community colleges in the state. }\end{array}$ \\
\hline $\begin{array}{l}\text { North } \\
\text { Carolina }\end{array}$ & 2009 & \multicolumn{2}{|l}{} \\
\hline
\end{tabular}

Table 3. Overview of Boards of Regent Actions for Undocumented Students

\begin{tabular}{|l|l|l|}
\hline State & $\begin{array}{l}\text { Year } \\
\text { Adopted }\end{array}$ & Notes \\
\hline $\begin{array}{l}\text { Rhode } \\
\text { Island }\end{array}$ & 2011 & $\begin{array}{l}\text { Policy adopted by the Rhode Island Board of Governors for Higher } \\
\text { Education allows for in-state tuition at the state's public institutions and did } \\
\text { not go into effect until 2012. }\end{array}$ \\
\hline Georgia & 2010 & $\begin{array}{l}\text { The policy of the Georgia State Board of Regents requires institutions of the } \\
\text { University of Georgia System to verify lawful presence for in-state tuition. }\end{array}$ \\
\hline Michigan & 2013 & $\begin{array}{l}\text { Policy adopted by the University of Michigan Board of Regents allow in- } \\
\text { state tuition for undocumented students. Other institutions in the state } \\
\text { have the authority to set their own policies concerning the matter. }\end{array}$ \\
\hline
\end{tabular}

